\title{
IDENTIFIKASI BAKTERI AEROB PADA LINDI HASIL SAMPAH DAPUR DI DUSUN SUKUNAN YOGYAKARTA
}

\author{
Mohamad Abdul Khamid, Surahma Asti Mulasari \\ Fakultas Kesehatan Masyarakat, Universitas Ahmad Dahlan Yogyakarta
}

\begin{abstract}
Background : Various human activities will generate waste. Trash can pollute the environment and as home to a wide range of diseases that can reduce the degree of human health, so that the waste be managed properly. Sukunan village was already implementing community-based integrated waste processing were independent and productive, clean and beautiful environment that involves all citizens in the implementation. The kitchen garbage management in the sukunan village is included in the composter to be composted with the results of liquid by bacterial degradation of organic material in the form of leachate. Leachate by the community Sukunan village used for liquid fertilizer plant and sold. The purpose of this study determined the genus of aerobic bacteria in the leachate of kitchen garbage result in Sukunan village.

Method : This research type was the descriptive research with laboratory test. The sample in this study was leachate of Sukunan village kitchen garbage result. The study was conducted in two places, in the Public Health Laboratory of Ahmad Dahlan University and in the Yogyakarta Health Laboratory Central. The results of data analysis was described in descriptive studies and presented in tabular and narrative.

Results : Identification of aerobic bacteria was carried in the Public Health Laboratory of the Ahmad Dahlan University get the bacteria that approached the characteristics of the genus Pseudomonas, Bacillus, and Escherichia / Salmonella / Aeromonas / Chromobacterium, while the results of identification carried out in the Health Laboratory Central in Yogyakarta got the bacterial genus such as Streptococcus (species : Enterococcus faecalis), Escherichia (species: Escherichia coli), Pseudomonas (species: Pseudomonas putrifaciens) and Proteus (species: Proteus vulgaris).

Conclusion : There has aerob bacteria in the leachate of kitchen garbage results in the Sukunan Village, Yogyakarta.
\end{abstract}

Keywords : Aerobic Bacteria, Leachate

\section{PENDAHULUAN}

Berbagai aktivitas manusia akan menghasilkan sampah atau produk samping yang dapat mencemari lingkungan, seperti pencemaran air, tanah, dan udara. Lingkungan padat/litosfer digunakan orang untuk membuang sampah yang bersifat padat. Selain itu, saat ini tanah juga digunakan untuk membuang sampah berbahaya cair maupun padat. Sampah ini ada yang dapat membusuk dan ada pula yang tidak mudah membusuk. ${ }^{1}$

Sampah sampai saat ini masih menjadi permasalahan yang serius bagi lingkungan. Hal ini dapat dilihat pada setiap daerah di Indonesia menghasilkan sampah yang terus meningkat. Sampah akan terus bertambah dan terus bertambah yang bisa menimbulkan masalah jika tidak ditangani dengan pengelolaan yang efektif dan efisien. ${ }^{2}$

Sampah berdasarkan bahan kimia yang terkandung di dalamnya terdiri atas sampah anorganik dan sampah organik. Sampah anorganik merupakan sampah yang tidak dapat membusuk seperti logam/besi, pecahan gelas, plastik, dan sebagainya. Sampah organik adalah sampah yang dapat membusuk, seperti sisa- 
sisa makanan, daun-daunan, buah-buahan, dan sebagainya. ${ }^{3}$

Sampah dapur merupakan sampah yang terdiri dari banyak sisa-sisa makanan, dan diduga memiliki kandungan $\mathrm{N}$ yang cukup tinggi, sedangkan limbah rumah tangga adalah limbah yang berasal dari dapur, kamar mandi, cucian, limbah bekas industri rumah tangga dan kotoran manusia. Limbah merupakan sesuatu yang tidak terpakai berbentuk padat, gas, dan cair. Dalam air limbah terdapat bahan kimia yang sukar untuk dihilangkan dan berbahaya. Bahan kimia tersebut dapat member kehidupan bagi kuman-kuman penyebab penyakit disentri, tipus, kolera dan penyakit lainnya. ${ }^{4}$

Sampah yang tidak dikelola dengan baik, dapat menurunkan etika dan estetika lingkungan, menimbulkan bau tidak sedap dan sebagai tempat berkembangnya berbagai macam penyakit yang dapat mematikan manusia. ${ }^{5}$

Pembuatan kompos merupakan salah satu cara untuk menghancurkan sampah secara biologis menjadi pupuk alami, sehingga sampah dapat dikembalikan ke tanah (return waste to the land). Hasil pengomposan ini tidak berbahaya bagi lingkungan dan manusia karena bahan organik yang ada pada sampah telah didegradasikan oleh organisme pengurai menjadi molekul-molekul yang sederhana melalui proses biologis, yaitu fermentasi secara cepat. Molekulmolekul sederhana ini dimanfaatkan oleh organisme tersebut sebagai bahan makanannya $^{5}$

Proses pengolahan lindi di Indonesia belum terlaksana dengan baik, seringkali lindi kurang dimanfaatkan dengan optimal. Jika pengelolaan lindi dapat diperbaiki, maka lindi yang biasanya sangat meresahkan masyarakat ini dapat dimanfaatkan sebagai pupuk cair yang sangat berdaya guna. Pupuk cair dari lindi dapat dihasilkan dari proses pembusukan bahan organik dengan menggunakan drum-drum dan dapat digunakan dengan disiramkan langsung ke tanaman.

Proses pengelolaan sampah di Sukunan, setiap rumah tangga memisahkan sampah berdasarkan jenisnya, yaitu plastik, kaca, logam, kertas dan sampah organik. Sampah plastik, kaca, logam, dan kertas masuk ke kantong terpisah, sampah organik masuk ke gentong kompos (bak komposter). Hasil samping pengomposan berupa lindi yang dimanfaatkan warga untuk pupuk cair tanaman dan sebagian dapat dijual ke warga atau instansi yang membutuhkan. Dari segi kesehatan masyarakat, pengolahan lindi dapat meningkatkan kelestarian lingkungan dan derajat kesehatan masyarakat.

\section{METODE PENELITIAN}

Penelitian ini adalah penelitian deskriptif kualitatif dengan menggunakan uji laboratorium untuk mengetahui bakteri aerob yang terdapat pada air lindi sampah dapur dusun Sukunan Yogyakarta. Penelitian ini dilaksanakan pada bulan April-Mei tahun 2011.

Variabel penelitian yang digunakan adalah variabel tunggal yaitu identifikasi bakteri aerob pada air lindi hasil sampah dapur di Dusun Sukunan Yogyakarta. Analisis data digunakan yaitu dengan teknik penjelasan (explanation-building) semua sumber diperiksa dan dievaluasi bersama sehingga temuan dalam studi tersebut merupakan gabungan informasi dari sumber yang berbeda. 
3. HASIL PENELITIAN DAN PEMBAHASAN

\section{A. Hasil Penelitian}

1) Hasil Penelitian di Laboratorium Fakultas Kesehatan Masyarakat UAD

Isolasi bakteri lindi sampah dapur yang dilakukan di Laboratorium Fakultas Kesehatan Masyarakat UAD dengan mengambil sampel $500 \mathrm{ml}$ dari Dusun Sukunan. Identifikasi dilakukan menggunakan metode plate dengan media PCA dan uji biokimia untuk yang dilakukan di Laboratorium FKM UAD hanya menggunakan uji katalase,. Hasil identifikasi dapat dilihat pada gambar berikut :

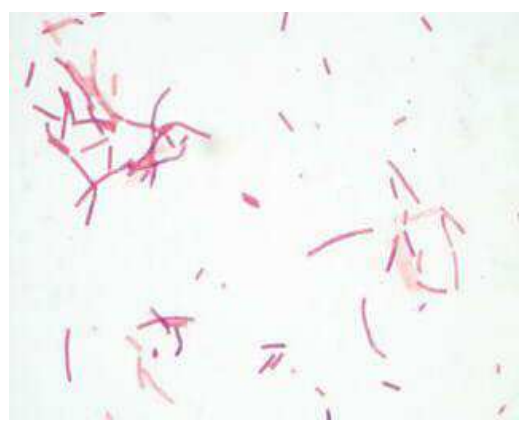

Gambar 1. Pengamatan Mikroskopis Isolat 1(Perbesaran 100:10)

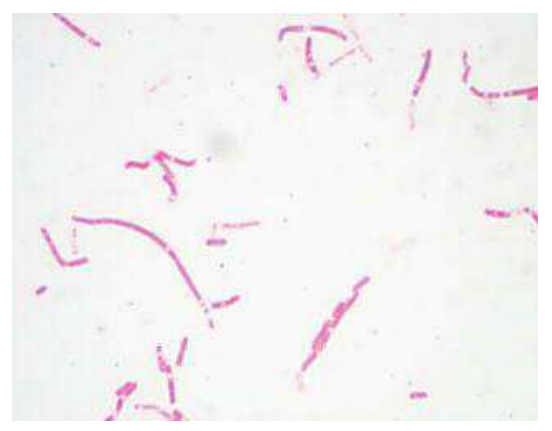

Gambar 2. Pengamatan Mikroskopis Isolat 2 (Perbesaran 100:10)

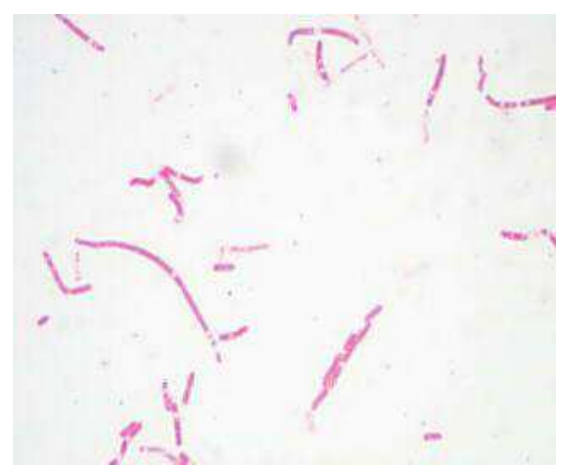

Gambar 3. Pengamatan Mikroskopis Isolat 3(Perbesaran 100:10)

(sumber : Data Primer)

Hasil pengamatan dengan menggunakan John's Bacterial Identification secara makroskopis, mikroskopis, dan uji biokimia yang dilakukan di Laboratorium Fakultas Kesehatan Masyarakat UAD dapat dilihat pada tabel 2 dibawah ini: 
Tabel 1. Hasil Pengamatan di Laboratorium FKM UAD Tahun 2011

\begin{tabular}{lccc}
\hline \multicolumn{1}{c}{ Pengamatan } & Isolat 1 & Isolat 2 & Isolat 3 \\
\hline Bentuk Koloni & batang & bulat & Bulat \\
\hline Warna Koloni & putih, mengkilat & putih, mengkilat & putih, mengkilat \\
\hline Motilitas & $+/-$ & $+/-$ & + \\
\hline Bentuk Bakteri & basil & basil & Basil \\
\hline Gram & - & + & - \\
\hline Uji Katalase & + & + & + \\
\hline $\begin{array}{l}\text { Genus yang } \\
\text { diperkirakan }\end{array}$ & Pseudomonas & Bacillus & $\begin{array}{c}\text { Escherichial } \\
\text { Salmonella / } \\
\end{array}$ \\
& & & $\begin{array}{c}\text { Aeromonas / } \\
\text { Chromobacterium }\end{array}$ \\
\hline
\end{tabular}

2) Hasil Penelitian di Balai Laboratorium Kesehatan Yogyakarta

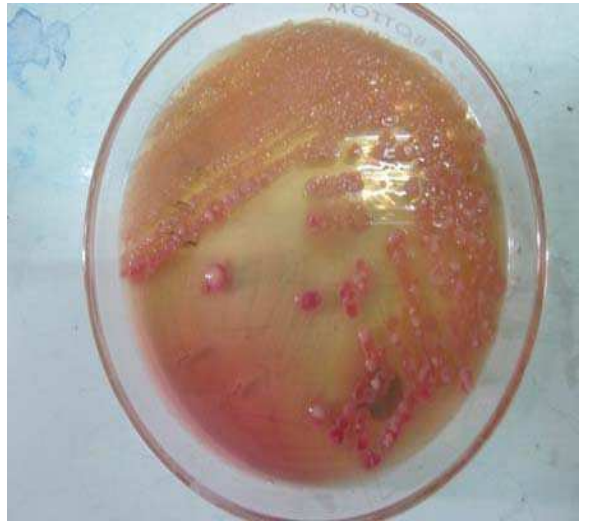

Gambar 4. Pengamatan Makroskopis Isolat 1 di BLK Tahun 2011

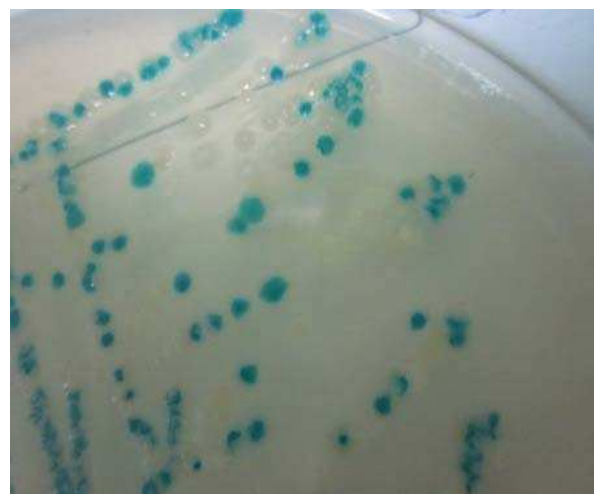

Gambar 6. Pengamatan Makroskopis Isolat 3 di BLK Tahun 2011

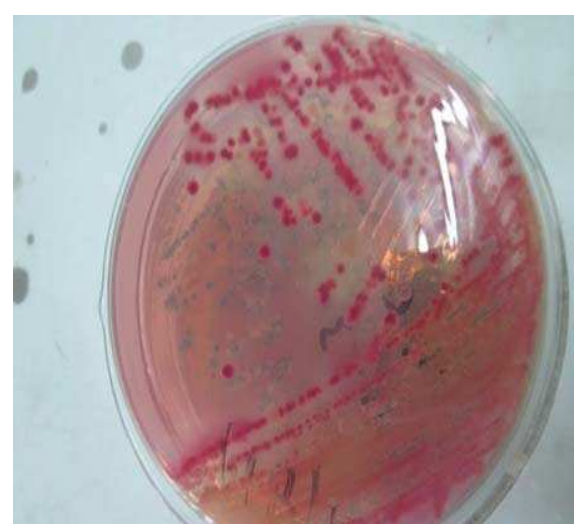

Gambar 5. Pengamatan Makroskopis Isolat 2 di BLK Tahun 2011

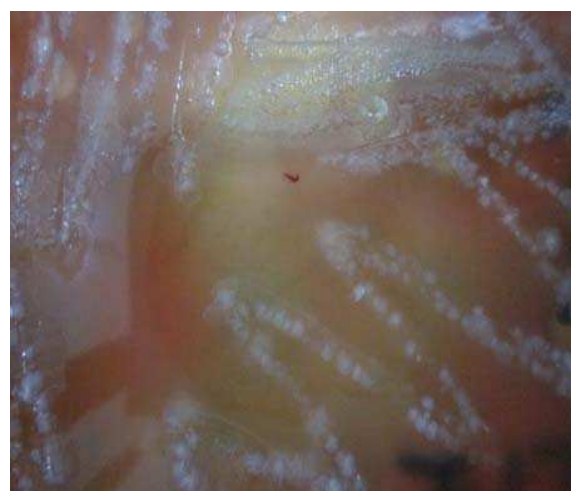

Gambar 7. Pengamatan Makroskopis Isolat 4 di BLK Tahun 2011

(Sumber : data primer)

Hasil pengamatan secara makroskopis, mikroskopis, dan uji biokimia yang dilakukan di Laboratorium FKM-UAD dapat dilihat pada tabel 3 berikut ini: 
Tabel 3. Hasil Pengamatan di BLK Yogyakarta Tahun 2011

\begin{tabular}{|c|c|c|c|c|}
\hline \multirow{2}{*}{$\begin{array}{l}\text { Pengamatan/ } \\
\text { uji biokimia }\end{array}$} & \multicolumn{4}{|c|}{ Isolat Bakteri } \\
\hline & Isolat 1 & Isolat 2 & Isolat 3 & Isolat 4 \\
\hline Bentuk Koloni & $\begin{array}{l}\text { Kecil, bulat, } \\
\text { berserabut }\end{array}$ & Bulat rata & Tidak teratur & $\begin{array}{c}\text { Kecil, } \\
\text { berpasangan } \\
\text { membentuk } \\
\text { rantai }\end{array}$ \\
\hline Warna Koloni & $\begin{array}{c}\text { Putih } \\
\text { kekuningan }\end{array}$ & $\begin{array}{l}\text { Abu-abu } \\
\text { kemerahan }\end{array}$ & Putih abu-abu & $\begin{array}{c}\text { Merah } \\
\text { muda/merah }\end{array}$ \\
\hline $\begin{array}{l}\text { Permukaan } \\
\text { Koloni }\end{array}$ & $\begin{array}{c}\text { Halus, } \\
\text { mengkilat, }\end{array}$ & $\begin{array}{l}\text { Halus mengki- } \\
\text { lat }\end{array}$ & Halus & Halus \\
\hline Bentuk Sel & Bulat & $\begin{array}{c}\text { Batang, } \\
\text { berpasangan/ } \\
\text { rantai }\end{array}$ & Batang & Batang \\
\hline Gram & + & - & - & - \\
\hline Glukosa & & + & $+/-$ & + \\
\hline Laktosa & & - & - & - \\
\hline Manitol & & + & - & - \\
\hline Maltosa & & + & - & + \\
\hline Sukrosa & & - & - & + \\
\hline $\mathrm{H} 2 \mathrm{~S}$ & & - & - & + \\
\hline Motility & + & $+/-$ & + & + \\
\hline Indole & & + & - & + \\
\hline Sitrat & + & - & + & $+/-$ \\
\hline Genus & Streptocccus & Escherichia & Pseudomonas & Proteus \\
\hline
\end{tabular}

\section{B. Pembahasan}

Lindi sampah dapur yang dihasilkan di Dusun Sukunan merupakan hasil samping dari pendegradasian berbagai bahan sisa aktivitas dapur yang berupa bahan organik. Sehingga lindi sampah dapur Dusun Sukunan adalah lindi hasil sampah organik. Lindi ini diambil sampelnya dan dilakukan proses isolasi dan identifikasi bakteri untuk menemukan tingkatan genus bakteri aerob.

\section{1) Identifikasi Bakteri Aerob Tingkat Genus pada Lindi Sampah Dapur Dusun Sukunan di Laboratorium FKM UAD}

Penelitian yang dilakukan di Laboratorium FKM UAD meliputi isolasi pada media PCA (Plate Count Agar), kemudian dilakukan pengamatan fisik bakteri melalui pengecatan Gram dan uji motilitas yang dilihat dengan mikroskop. Sedangkan uji biokimia yang dilakukan adalah uji katalase, yaitu dengan menggunakan $\mathrm{H}_{2} \mathrm{O}_{2}$.

Langkah awal dalam pengujian di Laboratorium FKM-UAD dengan pembiakan dan isolasi bakteri pada media PCA. Isolat yang tumbuh dari media tersebut, diidentifikasi lanjut yaitu pewarnaan Gram dan uji biokimia. Pewarnaan Gram digunakan untuk menentukan kelompok bakteri Gram positif dan bakteri Gram negatif. 
a) Isolat 1 (Pseudomonas)

Uji motilitas yang dengan mikroskop didapat hasil bergerak atau tidak bergerak. Uji pewarnaan Gram dengan menetesi isolat secara berurutan dengan larutan ungu kristal (UK), larutan Yodium, alkohol, dan safranin menunjukkan warna isolat bereaksi dengan larutan safranin sehingga warna menjadi berubah merah dan dikatakan termasuk bakteri Gram negatif.

b) Isolat 2 ( Bacillus)

Isolat 2 mempunyai cirri-ciri bakteri berbentuk basil atau batang, Gram positif dan bersifat motil atau tidak motil. Pada uji katalase dengan meneteskan reagen $\mathrm{H} 2 \mathrm{O} 2$ pada isolat 2 terdapat gelembung pada daerah yang ditetesi yang berarti uji katalase positif.

c) Isolat 3 (Escherichial Salmonella / Aeromonas / Chromobacterium) Isolat 3 mempunyai ciri-ciri bakteri berbentuk basil atau batang, bentuk koloni bulat, bakteri Gram negatif dan bersifat motil. Uji katalase positif dengan ditandai adanya gelembung pada daerah yang ditetesi reagen $\mathrm{H} 2 \mathrm{O} 2$. Hasil Identifikasi tersebut dengan menggunakan John's Bacterial Identification didapatkan empat genus bakteri yang masuk ciriciri tersebut yaitu Escherichial Salmonella / Aeromonas I Chromobacterium.

\section{2) Identifikasi Bakteri Aerob Tingkat Genus pada Lindi Sampah Dapur di} BLK Yogyakarta

Pengujian di BLK Yogyakarta dimulai dengan penanaman atau pembiakan sampel pada media diperkaya atau enrichment untuk kultur bakteri aerob menggunakan Brain Heart Infusion Broth (BHI), Thioglycolate Broth (TB), Soy Broth, dan Blood Broth. Setelah teridentifikasi adanya pertumbuhan bakteri, selanjutnya dilakukan isolasi bakteri aerob yang ada dengan menggunakan media isolasi Blood Agar Plate dan Mac Concey Agar Plate atau Azid Blood Agar Plate (khusus untuk genus Streptococcus).

a) Isolat 1 Enterococcus faecalis (genus: Streptococcus)

Penelitian yang dilakukan d BLK didapat hasil bahwa Enterococcus faecalis merupakan bakteri gram positif, motil, positif tumbuh pada media $\mathrm{BHI}$ broth dan Nutrient Broth $\mathrm{NaCl}$ 6,5\%.

Spesimen bakteri aerob pada lindi hasil sampah dapur Dususn Sukunan tumbuh pada media KF Streptococcus Agar Plate, hal ini menunjukkan adanya bakteri Streptococcus pada lindi ini yang diidentifikasi lebih lanjut merupakan spesies Enterococcus faecalis seperti hasil penelitian oleh Obire dan Agunda yang ditemukan bakteri Enterococcus sp.

b) Isolat 2 Escherichia coli (genus: Escherichia)

Identifikasi bakteri E.coli pada lindi hasil sampah dapur Dusun Sukunan di BLK dimulai dengan pengisolasian specimen pada media isolasi dan dilanjutkan dengan media pembiakan, antara lain EMB Agar, Endo Agar, Violet Red Blue Agar, trigitol 7 agar, dan TSI Agar. Hasil uji gula-gula positif pada fermentasi glukosa, manitol,dan maltosa, sedangkan negatif pada fermentasi laktosa dan sukrosa. Uji indol didapat positif, sedangkan uji $\mathrm{H} 2 \mathrm{~S}$ dan sitrat didapatkan hasil negatif 
dan motilitas dapat positif atau negatif.

Diagnosa Escherichia dalam Madigan, dkk (2003) ${ }^{7}$ menyatakan bahwa Escherichia pada uji H2S (TSI) dan urease adalah negatif, Uji indol positif dan motilitas didapat motil atau tidak motil.

c) Isolat 3 Pseudomonas putrifaciens (genus: Pseudomonas)

Bakteri yang mendekati genus Pseudomonas mempunyai ciri-ciri morfolog warna koloni putih susu atau agak kekuningan, bentuk koloni bulat, tepia timbul, sel bentuk bola, diameter 0,5-1,5 $\mu \mathrm{m}$, terjadi satu demi satu, berpasangan, dan dalam kelompok tidak teratur, Gram positif, tidak motil, katalase positif, oksidase negatif, metil red positif, tumbuh optimal pada suhu $30^{\circ} \mathrm{C}-37^{\circ} \mathrm{C}$ dan tumbuh baik pada $\mathrm{NaCl} 1-$ $7 \%$. Kajian ciri-ciri tambahan Pseudomonas adalah bakteri aerob dan dapat bergerak. ${ }^{8}$

Hasil identifikasi Isolat 3 menunjukkan isolate mendapat hasil positif pada uji sitrat dan motilitas, sedangkan hasil uji negatif pada uji indol dan uji gula-gula kecuali glukosa yang bisa positif atau negatif.

d) Isolat 4 Proteus vulgaris (genus: Proteus)

Hasil identifikasi pada isolat 4 yang dilakukan di BLK didapatkan hasil bahwa isolate adalah gram negatif, berbentuk basil, warna koloni merah muda atau merah, uji gula-gula negatif pada fermentasi laktosa dan manitol. Hasil uji positif pada uji motilitas, indol dan H2S, serta dapat memproduksi sitrat.

Hasil identifikasi ini diperkuat dengan penelitian yang dilakukan Fried $(2007)^{9}$ yang menyatakan Proteus vulgaris merupakan Gram negatif, tidak memfermentasi laktosa, motil, memproduksi indol, dan urease positif dengan ditandai perubahan warna menjadi menjadi merah karena adanya reaksi alkali dengan produksi amonia.

\section{SIMPULAN DAN SARAN}

\section{A. Simpulan}

Hasil identifikasi genus bakteri aerob pada lindi hasil sampah dapur Dusun Sukunan yang dilakukan di Balai Laboratorium Kesehatan Yogyakarta didapatkan genus bakteri genus Streptococcus (spesies: Enterococcus faecalis), Escherichia (spesies: Escherichia coli), Pseudomonas (spesies: Pseudomonas putrifaciens) dan Proteus (spesies: Proteus vulgaris).

Perbedaan hasil identifikasi bakteri lindi sampah dapur Dusun Sukunan yang dilakukan di Laboratorium FKM-UAD dengan di BLK Yogyakarta karena adanya perbedaan ketersediaan media bakteri, uji bakteri yang dilakukan, dan ruangan penelitian.

\section{B. Saran}

Berdarakan hasil penelitaian yang diperoleh, maka disarnakan beberapa hal berikut ini :

1) Perlu dilakukan penelitian lanjutan pada tingkat spesies bakteri lindi hasil sampah dapur guna lebih diketahui spesies yang dapat bermanfaat dan spesies yang patogen dengan cara penanganannya sehingga lindi lebih dapat dimanfaatkan dan lebih menjaga kesehatan lingkungan serta 
pengelolanya.

2) Sebaiknya peralatan dan reagen untuk isolasi dan identifikasi bakteri di Laboratorium FKM UAD lebih diperlengkap serta penyediaan ruang yang lebih mendukung untuk kegiatan identifikasi bakteri.

\section{DAFTAR PUSTAKA}

1. Slamet, J. S., Kesehatan Lingkungan, Hal 150 - 158, Gadjah Mada University Press, Yogyakarta. 2004

2. Dewi, Q. T., Penanganan dan Pengolahan Sampah, Penebar Swadaya, Jakarta. 2008

3. Notoatmodjo, S., IImu Kesehatan Masyarakat Prinsip-Prinsip Dasar, Hal 166 - 169, Rineka Cipta, Jakarta. 2003

4. Sulistyawati, E., Mashita, N., dan Choesin, D. N., Pengaruh Agen Dekomposer terhadap Kualitas Hasil Pengomposan Sampah Organik Rumah Tangga, Makalah Seminar Nasional Penelitian Nasional, ITB, Bandung. 2008

5. Sukandarrumidi, Rekayasa Gambut, Briket Batubara, dan Sampah Organik, Gadjah Mada University Press, Yogyakarta. 2009

6. Purwendro, S dan Nurhidayat, Mengolah Sampah untuk Pupuk dan Pestisida Organik, Hal 5 - 18, Penebar Swadaya, Depok. 2008

7. Madigan, M. T., Martinko, J. M., dan Parker, J., Biology of Microorganisms, Ed. Ke10, Hal. 375-379, Pearson Education Inc, USA. 2003

8. Jawetz, E., Melnick, J., dan Adelberg, E., Mikrobiologi Kedokteran, Terjemahan, Edisi ke-20, Hal 38 - 287, EGC, Jakarta. 1996

9. Fried, Danielle, Metabolism and Biochemical Tests, Raleigh, USA. 2007 